\title{
Public lies, private looting and the forced closure of Grootvlei Gold Mine, South Africa
}

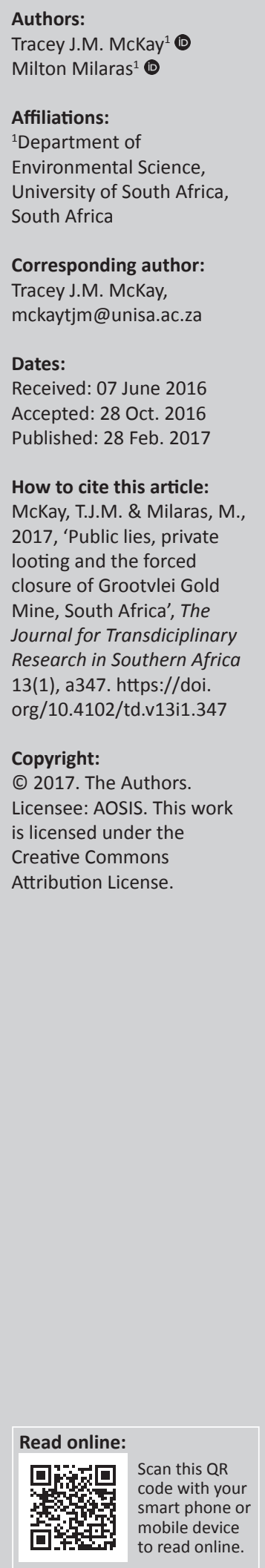

Mine closure and acid mine drainage (AMD) are major interrelated challenges facing South Africa's Witwatersrand gold mines. As a result of mining, the East, West and Central Rand compartments of the Witwatersrand Basin are interconnected, making AMD a regional problem. Consequently, the South African National Department of Mineral Resources recommends regional mine closure strategies. Unfortunately, the mismanagement of Grootvlei Gold Mine and its AMD problem resulted in premature and unplanned closure of the mine; massive job losses; pollution of a river and its Ramsar wetland site, as well as a significant setback for regional mine closure. Although directors were held civilly liable for damages to the mine, to date no one has been held liable for the water pollution, creating an impression that environmental laws can be flouted with impunity.

\section{Introduction}

Gold mining has been ongoing in the Witwatersrand Basin since 1886, with a cumulative impact on the region's land, water quality and ecosystems (Tutu, McCarthy \& Cukrowska 2008). Rehabilitation is expensive, in part because impacts do not cease when a mine closes and the impacts are multiple. Moreover, the South African gold mining industry is in its 'sunset stage', creating major cash-flow challenges for the proper management of impacts (de Wet \& Sidu 2013). One well-known and major impact is that of acid mine drainage (AMD) (Blowes et al. 2014; Bremmer 2013). The impact of AMD is a regional one, as underground workings are prone to flooding. If water is not consistently pumped out, underground tunnels become unworkable which may lead to forced mine closure. But pumping brings the AMD to the surface. As the underground tunnels of various mines are often connected, cessation of pumping (and subsequent flooding) of one mine threatens others (de Wet \& Sidu 2013; McCarthy 2011). Thus, mines must pump this AMD even if the AMD is not actually a result of their own mining. AMD, however, is a threat to the freshwater systems of the Vaal Barrage sub-catchment and Vaal River, as well as the Crocodile West and Limpopo Rivers (Durand 2012). Therefore, any water pumped out by mines must also be treated to ameliorate such pollution. Consequently, the management of AMD is a major concern both for government and mining operations. In the case of financially stressed, end-of-life mines, such AMD responsibilities can become a serious financial burden in times of diminished cash flow (Milaras, Ahmed \& McKay 2014).

This is a study of the Grootvlei Gold Mine (see Figure 1) situated in Springs, east of Johannesburg. Declining gold production has resulted in mine closures and the progressive cessation of AMD pumping regimes in the region, leaving Grootvlei the last operational gold mine on the East Rand Basin (McCarthy 2011). All responsibility to pump and treat AMD thus fell to Grootvlei, as the Eastern Basin's interconnected underground tunnels placed substantial water pressure on Grootvlei's operations. If the mine did not dewater, it would not be able to maintain production (Durand 2012). However, as Grootvlei was not always able to cope with both the cost of pumping and treating huge volumes of acidified water, untreated AMD was often pumped straight into the Blesbokspruit River System (Fourie 2009).

\section{An overview of the AMD problem facing the Witwatersrand}

The gold mines of the Witwatersrand region connect three sub-basins: the East Rand, West Rand and Central Rand (see Figure 2). To varying extents, all three face an AMD problem (DWA 2011). AMD forms when rocks that contain sulphide mineral pyrite $\left(\mathrm{FeS}_{2}\right)$ are exposed to oxygenated air and water. The resultant oxidisation leads to the formation of sulphuric acid and ferrous sulphate, or AMD (Blowes et al. 2014). AMD is saline, acidic, rich in mobilised heavy metals and thus highly toxic. 


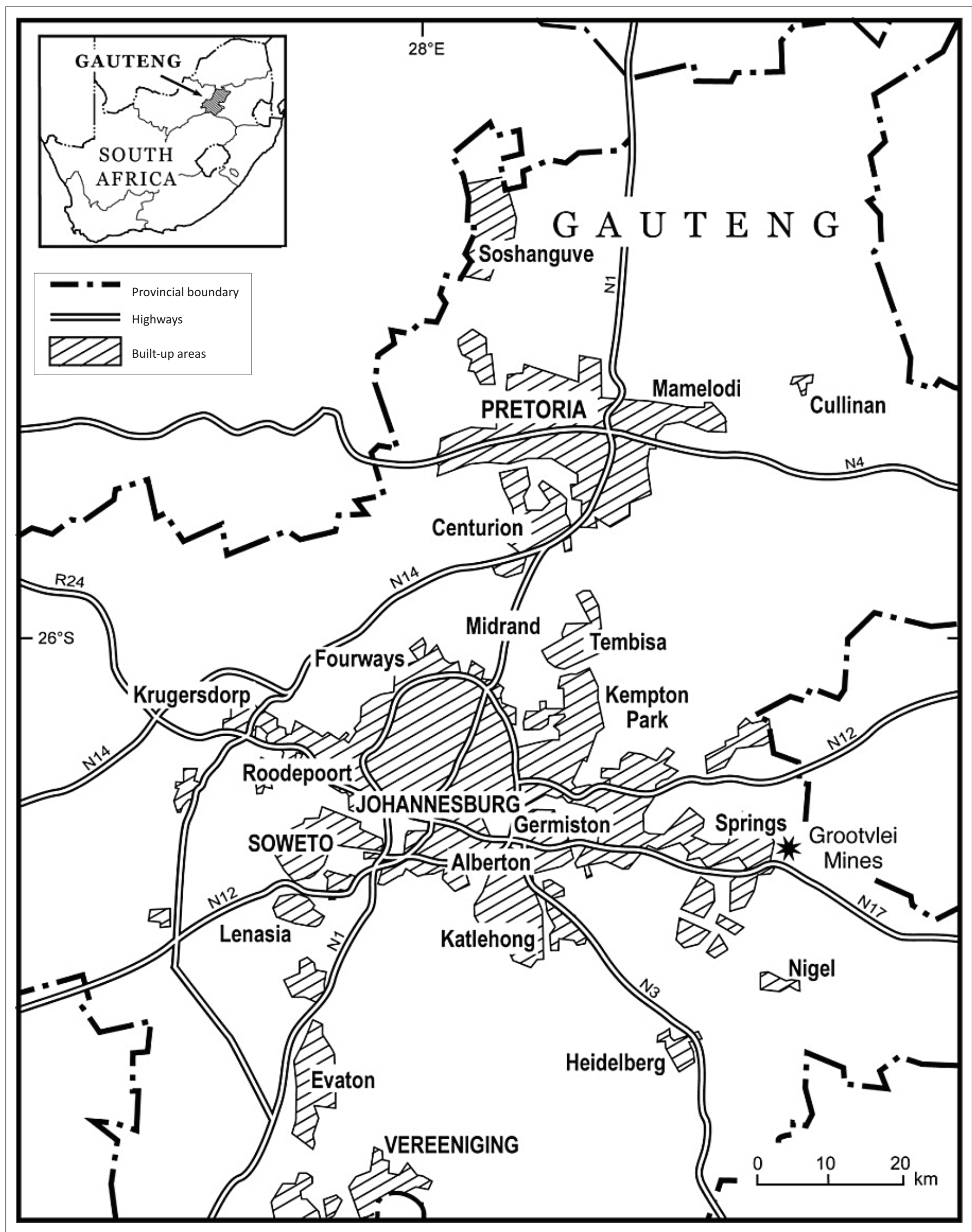

Source: Authors own work.

FIGURE 1: Grootvlei Gold Mine, Gauteng, South Africa. 


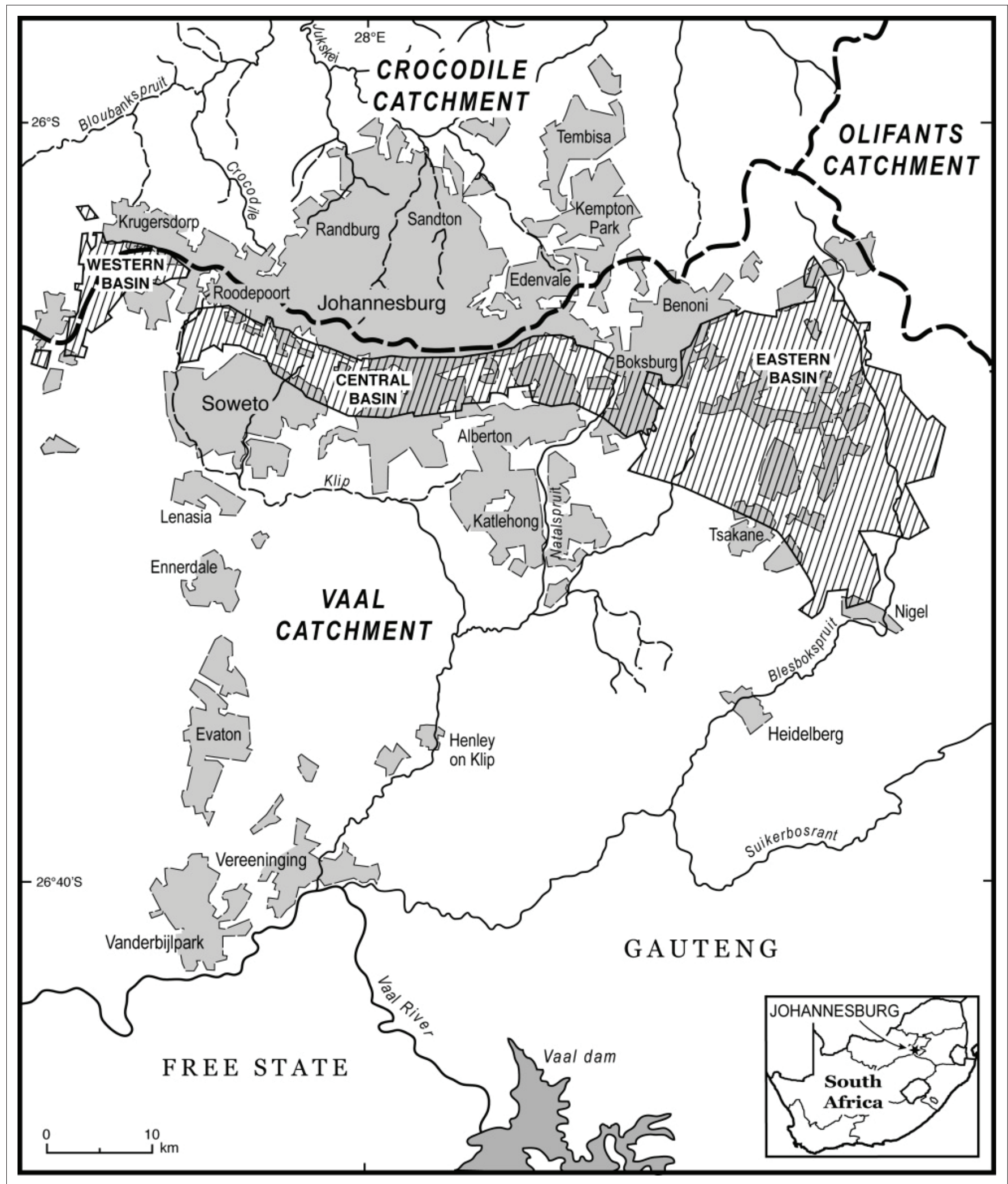

Source: Authors own work.

FIGURE 2: The three Witwatersrand sub-basins and the associated water catchment areas of the Upper Vaal. 
Management of AMD, therefore, requires (inter alia) acid neutralisation regimes. Although ideally source control techniques (preferably in the initial mine design) should be implemented, AMD on the Witwatersrand has been managed with 'reactive' control techniques (Murphy, Taylor \& Leake 2012).

In 1957, the first report on the AMD problem in the Witwatersrand was released, although no action was taken to deal with it, until the severity of the AMD decant problem became apparent. Then, a treatment plan was presented to parliament in 1996. The plan was accepted in 1998, but again, little action was forthcoming. Mining and its associated underground dewatering practices first ceased on the West Rand in the 1990s, causing the old mine voids to flood (McCarthy 2010; Winde \& Stoch 2010). Consequently, by August 2002, AMD began decanting to surface from an abandoned Randfontein Estates Ltd mine shaft in Mogale City into the Tweelopiespruit and Wonderfonteinspruit (Bremmer 2013; Hobbs \& Cobbing 2007). It was only then the nature of the environmental risks to freshwater resources, as well as the socio-economic consequences, began to be realised (Ewart 2011). As all mining (and pumping) ceased in the Central Basin in 2008, it is expected that a similar situation will develop there. Despite this escalating situation, many mining companies appear to have little appetite for upgrading water treatment facilities or adhering to legislation designed to deal with the problem, resulting in perceptions that they are unwilling to take responsibility for the AMD problem (Hobbs, Oelofse \& Rascher 2008; McCarthy 2010).

The decanting of AMD on the West Rand resulted in a massive outcry by environmentalists, NGOs and the media (Bremmer 2013). Consequently, the Minister of Water Affairs established an inter-ministerial committee (IMC) in 2010 (McCarthy 2010). This IMC was a specialised technical team tasked with investigating the problem and proposing a viable solution for the short, medium and long term. Task team members were made up of employees from the Department of Water Affairs (DWA), Department of Mineral Resources (DMR), Council for Scientific and Industrial Research (CSIR), Council for Geoscience (CGS) and Mintek and Water Research Commission (WRC). Cabinet adopted the final recommendations of the IMC report in January 2011 and, following pressure from NGOs, released it to the public in February 2011 (Ewart 2011). The task team report maintained that the AMD problem needed urgent attention and proposed solutions that drew on international (and national) best practices concerning water ingress, AMD generation and decanting, namely: (1) reduce the volume of water ingress into the shafts, (2) undertake to install flood and decanting management solutions so as to reduce the need to pump, (3) accurately predict when and where decant will occur once pumping ceases, (4) undertake to monitor the impact of underground mine flooding, (5) undertake an analysis of the impact of AMD on the environment and human health risks, and (6) ensure that uncontrolled decanting of AMD is avoided. Funds for the rehabilitation of abandoned mines and the financing of AMD have proven to be highly controversial and problematic, as has prosecution of the accountable mining companies (de Wet \& Sidu 2013). The delays in taking action have been prolonged by both the government and mine owners, each claiming that the other is ultimately responsible and, thus, should pay for AMD treatment (Milaras et al. 2014).

\section{Environmental rights, environmental legislation and acid mine drainage}

South Africa has a strong legal regime promoting environmentally responsible mineral extraction and mine closure. Legislation includes the following: (1) the MPRDA or Mineral and Petroleum Resources Development Act No. 28 of 2002, enforced by the Department of Mineral Resources (DME), (2) the NEMA or National Environmental Management $A c t^{1}$ No. 107 of 1998, enforced by the Department of Environmental Affairs (DEAT 1998) and (3) the NWA or National Water Act No. 36 of $1998,{ }^{2}$ enforced by the Department of Water and Sanitation (DWAF 1998). Both NEMA and the NWA (particularly Section 19) demand reasonable pollution prevention measures where a duty of care falls to the owners, managers or land occupiers. NEMA also makes provision for the polluter to pay for rehabilitation. The MPRDA demands mines manage mine-related pollution, holds them responsible for both preventing the pollution and paying for rehabilitation, as well as dictates what must occur in the event of mine closure. ${ }^{3}$ Thus, South African legislation imposes a duty of care on mine owners, a legal and financial responsibility for mine closure and the remediation of environmental degradation. Key compliance tools available to government officials are permits, compliance notices and directives. Noncompliance is a criminal offence (Paterson \& Kotzé 2009). Despite this, Liefferink and van Eeden (2010) raise concerns that government departments do not see AMD as an urgent problem, nor is there enforcement of the legislation. Overall, South Africa has a poor track record with respect to compliance with, and enforcement of, environmental laws, and government departments, the courts, as well as public and private institutions seldom work together to ensure compliance and enforcement (Paterson \& Kotzé 2009). This weak response is partly owing to the perception that the environment should be leveraged for socio-economic growth (Strydom \& King 2009).

\section{Methodology, aims and research questions}

This study used an inductive, qualitative case study framework (Yin 2011). The study sought to (a) establish the pattern of ownership and management of the Grootvlei Gold Mine and (b) detail the consequences of the mismanagement of both the mine and its AMD. Historical time sequencing of events using archival material and an inductive analytical

1.Sections $2 ; 24 ; 24 \mathrm{R} ; 28 ; 32 ; 33$.

2.Section 19 .

3.Allowing a viable mine to close because of negligence may also be known as unplanned, forced or catastrophic closure. 
approach was undertaken (Eisenhardt \& Graebner 2007). The historical timeline was constructed using specialised reports, newspaper articles and online archival records, and they are accordingly referenced in line as primary data, with author and exact date. A two-tier search for all available online articles was conducted. Google searches, using key words (Aurora Empowerment Systems, Pamodzi Gold, Grootvlei, AMD and Acid Mine Water) led to the following 16 source websites: Mining Weekly, News 24, SAPA, Mail \& Guardian, SAPA, Eyewitness News, Business Report, The Star, TimesLive, Fin 24, The Sunday Times, Legal Brief, Associated Press, e-News online, City Press and Africa Report. Thereafter, a search of each website was undertaken in order to find all relevant articles published. These online sources totalled 272 pages, with contributions from 29 different writers/authors. ${ }^{4}$ From this data set, information pertaining to mine ownership, government action, the behaviour of the liquidators, owners and the relevant trade unions was extracted. This study has some limitations: some of the sources presented contradictory or differing views and the authors were not able to obtain confidential government and corporate documentation. Thus, the study is limited to the extensive media reports and the Bertelsmann Judgement. Follow-up studies to clarify and support the findings presented here are recommended.

\section{Grootvlei Mine: Its surroundings and AMD problem}

Grootvlei Mine is situated in the far east of the East Rand Basin (Lea, Waygood \& Duthie 2003). The mine is located 3 $\mathrm{km}$ east of Springs and borders Consolidated Modderfontein (Cons Modder) Mine and Nigel Mine (Thorius 2004). Grootvlei had been actively mined for more than 80 years prior to its forced closure in 2011 (Palmer, Waygood \& Lea 2006). There were four production shafts (Shafts: 1, 4, 6 and 8). The primary water pumping shaft was Shaft No. 3. Grootvlei made use of a high density separation (HDS) plant and numerous settling ponds to treat AMD (Van der Merwe \& Lea 2003). Subsequently, water flowed into the Blesbokspruit River, which was a typical non-perennial, meandering Highveld stream. The river also has a wetland, known as the Marievale Bird Sanctuary and Wetland, which is a designated Ramsar site. The river is a tributary of the Suikerbosrand River, which flows into the Vaal River (see Figure 3) (Dini 1998). Both the Blesbokspruit and the wetland have been degraded by both urban and mining-related developments, and its conservation status is deemed threatened (Thorius 2004).

Between 1995 and 2003, a number of investigations on water ingress at Grootvlei were undertaken (see Barradas \& Loggenberg 1996; Jones \& Wagener (Pty) Ltd., 2003; Scott 1995; Wates, Meiring \& Barnard (Pty) Ltd. 2002).

4.Adriana Stuijt, Bongani Mthethwa, Christine Leondardi, Christy van der Merwe David Fig, David Masondo, David McKay, Dewald van Rensburg, Dianne Hawke, Ernest Wolmans, Ernest Wolmarams, Gabi Falanga, Gertrude Makhafola, Gill Gifford, Idele Esterhuizen, llham Rawoot, Inge Salgado, Jana Marais, Jeanne van der Merwe, Jocelyn Newarch, Johan Jonck, Karabo Keepile, Khadija Sharife, Liesel Frankson, Lon Prinsloo, Lucky Biyase, Lynley Donnelly, Mara Kardas-Nelson, Mariaan Webb, Marti Creamer, Martin Plaut, Martin Zhuwakinyu, Megan Wait, Meshack Mbangula, Natasha Marrian, Sally Evans, Sipho Masondo, Yolandi Groenewald, Tyler Durden, Zwanga Mukhuthu. Note these media reports are referenced in line by author and the exact date of the article.
These studies found that approximately $65 \%$ of Grootvlei's underground mine water originated from surface water, and thus, seasonal rainfall patterns exacerbate the underground flooding and AMD problems (Palmer et al. 2006). Jones and Wagener (2003) suggested a canal be built to reduce ingress volumes and to significantly reduce the volume of AMD and the amount of pumping and treatment required. But as another study felt that the canal would negatively affect the Blesbokspruit, it was not built (Palmer et al. 2006). No other plans to limit surface water ingress were ever tabled.

\section{Findings: Mining operations at Grootvlei Gold Mine, a historical analysis}

By the 1970s, gold mining on the East Rand was in decline. Difficult operational conditions were caused by a decline in the gold price, a decline in the already low-grade gold reserves, rising costs and increased water ingress (Baartjes \& Gounden 2012). Because of the poor financial conditions, government subsidised the pumping and treatment of AMD from the East Rand with a sum of R8 million a month (Marius Keet, Parliamentary Portfolio Committee on Water and Environmental Affairs, AMD public hearings 20 April 2011). During the 1990s, GenGold Ltd. and Harmony Gold (Pty) Ltd. jointly owned Grootvlei and Consolidated Modderfontein (Cons Modder) Mine (last actively mined in 1962) (Plaut 2011). Eventually, in 1991, only Grootvlei Mine remained operational, making it the last remaining East Rand mine pumping and treating AMD (McCarthy 2011). By October 1995, the volume and the cost of pumping and treatment (of what was essentially the entire Eastern Basin) overwhelmed Grootvlei and massive volumes of untreated AMD (between 75 and 80 megalitres per day) flowed into the Blesbokspruit (McCarthy 2010). The result was salination of the soil within the region and a decrease in water quality (Thorius 2004). In 1996, the Department of Water Affairs and Forestry (DWAF) issued Grootvlei with a water permit despite the water having high levels of sulphates and iron concentrations (McCarthy 2010). This permit was revoked once it became clear that Grootvlei was contaminating the wetland with red iron oxide particulate matter (Van der Merwe \& Lea 2003). In late 1996, a second dewatering permit was issued but stipulated that Grootvlei had to install six iron and sulphate settling ponds and a HDS water treatment plant to remove metal contaminants (Fourie 2009; Lea et al. 2003). Despite this, the water still contained high levels of sulphates. Once the HDS plant was fully operational, Grootvlei was issued a third permit to legalise the discharge of this partially treated water into the Blesbokspruit (Lea et al. 2003). Subsequently, HDS quantity and quality monitoring data supplied by Grootvlei indicated that the mine was operating within its (somewhat lenient) permit restrictions (de Wet \& Sidu 2013).

In 1997, Harmony Gold (Pty) Ltd. bought out GenGold Ltd.'s share in the two mines. Subsequently, in 1998, both Cons Modder and Grootvlei were sold to Petmin Ltd. (Salgado, 28/02/2011). Soon thereafter (in 2000) Petrex (Pty) 


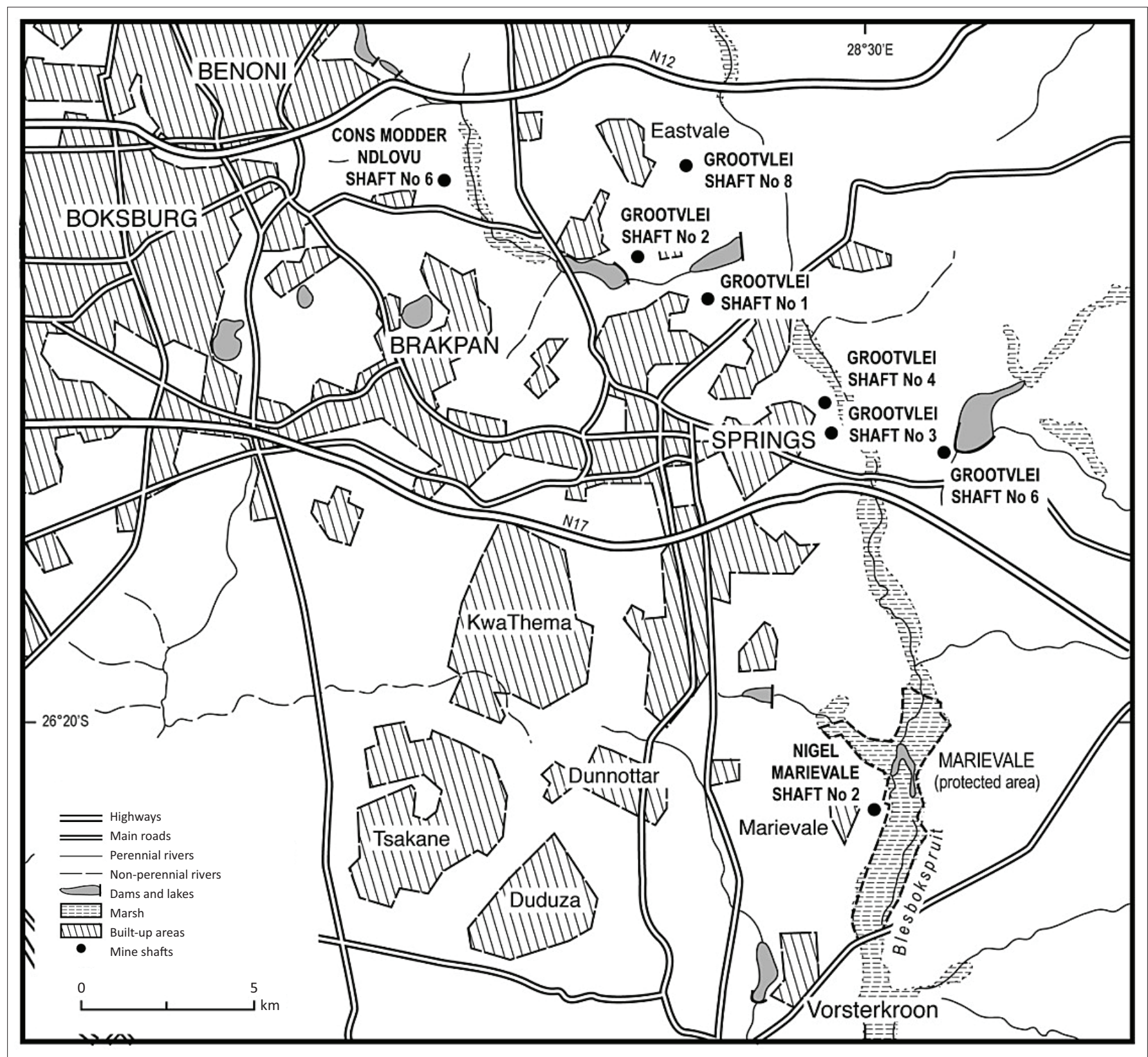

Source: Authors own work.

FIGURE 3: Location of Grootvlei mining shafts, the Blesbokspruit and Marievale Ramsar site.

Ltd. (part of Bema Gold Corporation, Canada at the time) bought both mines, as well as neighbouring Nigel Mining Company's mine (Salgado, 28/02/2011). Pamodzi Gold Ltd. purchased a controlling stake in Bema's Gold East Rand operations in December 2006 and, in doing so, took control of all three mines (Plaut 2013). Things did not go well, and by early 2009, Pamodzi Gold Ltd. began to suffer financially. Thus, the holders of the gold hedge, Unicredit and HypoVereinsbank of Germany, both had to invest money to keep the mine afloat (Creamer, 06/10/2009 \& 08/06/2010). The state-owned Industrial Development Corporation (IDC) was also a major secured creditor (Creamer, 19/03/2010).

In a bid to reduce costs, the pumping and treatment of AMD, already confined to off-peak hours (to benefit from Eskom's off-peak electricity tariffs), were significantly reduced, threatening the viability of the mine as the water level rose
(Creamer, 29/04/2009). With Pamodzi Gold Ltd. experiencing cash-flow problems and facing provisional liquidation, the DME allocated R7.5 million to assist the mine with some of the pumping costs (Creamer, 29/04/2009). Justification for the subsidy was based on the need to prevent the flooding of the mine 'at all costs' and that the 'fairly new pumping infrastructure ... had to be saved'. This was because if AMD were to decant and remain untreated 'tons of poisonous ferrous and ferric acids will flow into the river' (Marius Keet, Deputy Director, DWS, in Stuijt, 10/03/2010). At this point, the South African government committed to spending at least R2.5 million per month to support AMD pumping and treatment in the East Rand Basin, a sum which represented roughly half of Grootvlei's monthly pumping cost (SABCs $50 / 50,07 / 06 / 2010) .{ }^{5}$ However, it seems that this money was 5.Although in July 2010 Zondwa Mandela said pumping cost R6.5 million a month (Jonck, Fin24, 27/07/2010; SAPA, 04/08/2010). 
not paid across on a regular basis and mine managers often had to beg to get the transfers effected (Creamer, 29/04/2009; Stuijt, 10/03/2010). One reason for the delay in payments may be owing to Grootvlei failing to submit external laboratory certified water quality reports. Cash-flow problems had resulted in the laboratory been unpaid; consequently, they refused to do more work for the mine. The last laboratory report submitted by Grootvlei to DWS was June 2009 (SABCs 50/50, 07/06/2010). Intermittent pumping resulted in corrosion of underground steelworks and concerns began to be raised about possible underground flooding (Creamer, 19/03/2010 \& 26/03/2010; Naidoo, 07/05/2009; Masondo, 18/01/2011). In a further bid to reduce costs, the treatment plant used less and less lime, flocculent and oxygen (Naidoo, 07/05/2009; Salgado, 28/02/2011). Consequently, the AMD concentrations in the Blesbokspruit worsened.

By late 2009, Pamodzi Gold Ltd. was facing provisional liquidation. Many employees were put on unpaid leave, whereas others were on a work stoppage over non-payment of wages. By September and October 2009, the company went into final liquidation (Creamer, 12/10/2009). Six liquidators were appointed. Soon thereafter, Enver Motala, as the lead liquidator, announced that Aurora Empowerment Systems (Pty) Ltd.'s bid of R495 million for Grootvlei had been accepted (Salgado, 28/02/2011). The Managing Director of Aurora Empowerment Systems (Pty) Ltd. is Zondwa Mandela (Nelson Mandela's grandson), its Chairperson is Khulubuse Zuma (Jacob Zuma's nephew), and three other directors were Sheshile Thulani Ngubane (Commerical Director), Fazel and Solly Bhana (Creamer, 12/10/2009 \& 26/04/2010; Prinsloo, 07/04/2010). At the time, financial backing was said to be coming from Malaysia and the Middle East. Later on, it became clear that there was no such funders and that the liquidator had been warned of this at the time (Creamer, 12/10/2009; Hawker, 25/08/2014). Despite this, Sandra du Toit of Standard Bank testified (in a later High Court enquiry) that Motala refused to entertain any other offers for the mine (Hawker, 25/08/2014). In October 2009, Aurora paid a deposit of R10 million and took control of the shafts (four at Grootvlei; one at Nigel and one at Cons Modder) and the one pump station (Van der Merwe \& Lea 2003; Wates, Meiring \& Barnard 2002). Aurora promised to invest R600 million to upgrade and rehabilitate mine infrastructure, establish a community trust, provide health care services, fund housing purchases for employees, provide bursaries for employee's dependents and retain all the workers at the mine (Creamer, 12/10/2009 \& 19/03/2010). Around the same time, some of the Aurora directors also offered R376 million (R296 million in cash for a 60\% share, and R80 million as working capital) for DRD Gold's financially troubled, and under judicial management, Blyvooruitzicht mine on the West Rand (Creamer, 11/12/2009; Marais, 06/08/2014).

However, once Aurora took control of Grootvlei, the HDS plant was shut down (de Wet \& Sidu 2013). The Financial Manager (Fazel Bhana) blamed a lack of payment of the governmental pumping subsidy for this (Stuijt, 10/03/2010). The mine was also beset with fatalities, resulting in two separate notices by the DME to cease operations, although the Aurora directors were able to make use of their political connections to continue mining (Seccombe, 29/08/2014; Bertelsmann, 25/06/2015). By January 2010, inconsistent pumping practices rendered two Grootvlei mine shafts permanently flooded (SAPA, 27/01/2010). Later, a third shaft also flooded (Stuijt, 10/03/2010; Fig, 2011). During this period, Aurora's MD maintained that Grootvlei was producing $150 \mathrm{~kg}$ of gold a month, although the Financial Manager said the amount of gold being mined was minimal ${ }^{6}$ (Creamer, 11/12/2009; Stuijt, 10/03/2010). It was later established that Grootvlei had produced at least R81 million in gold between October 2009 and March 2010, although the trade union Solidarity has argued that R122 million is a more accurate figure (Groenewald \& Rawoot, 26/03/2010; Wolmarans, 25/11/2011; Evans, 04/05/2012). The mine also suffered from intermittent work stoppages, as miners downed tools demanding their salaries. Aurora cajoled (some allege threatened) them into returning to work, but when promises of payment went unfulfilled, they downed tools again (Prinsloo, 31/03/2010; Creamer, 19/04/2010). Both Solidarity and another trade union, the National Union of Mineworkers (NUM), claimed that Aurora either underpaid or failed to pay its estimated 5200 employees. Nor were the other promises (such as housing) ever met (Creamer, $19 / 03 / 2010)$. As the mine appeared to be bereft of any on-site managers, shop stewards were forced to engage directly with the liquidators. NUM called for the DMR to intervene (Prinsloo, 25/03/2010). This did not happen, and by March 2010, Aurora laid off 1440 workers citing cash-flow problems (Creamer, 19/03/2010; Prinsloo, 26/03/2010). Various suppliers also went unpaid (Groenewald \& Rawoot, 26/03/2010; Creamer, 17/06/2011). Non-payment resulted in Eskom cutting off the mine's power supply (the debt was R54 million) and the security contractor withdrawing its services, which caused a substantial increase in illegal mining (SAPA, 05/11/2014). Reports started to emerge of unpaid miners engaging in illegal mining and cable theft (Prinsloo, 07/04/2010; Prinsloo, 12/08/2010; Keepile, 07/09/2010). Rand Mutual also cancelled Grootvlei's insurance policy owing to non-payment (Groenewald \& Rawoot, 14/05/2010). In April 2010, Aurora claimed it had paid wages for February 2010 and that an agreement with the trade unions had been signed to restart operations so that the remaining outstanding wages could be paid (Prinsloo, 07/04/2010; 09/04/2010; Creamer, 24/05/2010). Miners did return to work, but when only a portion of the outstanding salaries were paid, strike action recommenced (Prinsloo, 31/03/2010). Trade unions were by now openly expressing their unhappiness with the situation. For example, NUM and Congress of South African Trade Unions (COSATU) spokesperson said ‘We have been very soft on the Aurora management for too long. It is about time to expose the type of management that Aurora has'

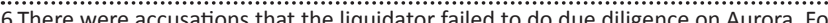
example, it emerged that Fazel Bhana had a questionable financial history having been fined by the Financial Services Board (FSB) for insider trading and arrested on been fined by the Financial Services Board (FSB) for insider trading and arrested on
charges of VAT fraud (Groenewald \& Rawoot, 14/05/2010, 26/03/2010; McKay, charges of VAT fraud (Groenewald
06/02/2011; Evans, 24/10/2014). 
(in Prinsloo 31/03/2010). In turn, Aurora said wages could only be paid if the mine was in production and, as such, urged workers to return to work (Prinsloo 14/04/2010). This did not happen and the mine effectively ceased operations on 19 March 2010 (SABCs 50/50, 07/06/2010). Despite this, Aurora continued to claim that their takeover of the mine was on track, funding from a private international equity fund had been secured and the proposed listing on the Johannesburg Stock Exchange (JSE) would proceed (Prinsloo, 14/04/2010). The lead liquidator continued to support Aurora's offer to purchase, indicating that Switzerland's Global Emerging Markets (GEM) had pledged equity capital once Aurora was listed (Creamer, 26/04/2010; 08/06/2010). Later on, GEM claimed that their (one and only) investment (of R13 million) was personally facilitated by President Jacob Zuma and GEM thought the money was to pay Grootvlei wages. There is no evidence that wages were paid with GEM's money, or even that Aurora received the cash. President Zuma has not made any comments on GEM's allegation at all (Evans \& Sole, 16/05/2014).

At the behest of the unions, a management and gold sales audit was undertaken. This audit revealed attempts by directors to use company cheques (that bounced) to pay personal debts (Groenewald \& Rawoot, 14/05/2010). By June 2010, roughly 100 pump station workers downed tools over non-payment. At the time, Marius Keet of DWS said he was 'extremely concerned' about the situation and 'would have to intervene if pumping ceased again' as 'the department will not allow the mine to flood the pumps as this will result in the flooding of the [Eastern] basin and subsequently the decanting of acid mine drainage' (in Groenewald, 11/06/2010).

Aurora management again persuaded the workers to return to work on the promise of payment. This spurned the economist Mike Schussler to say that these Aurora workers were effectively working 'in the hope that they may be paid' and that, as they were doing so without life insurance, both the Department of Labour and South African labour laws had failed them (SAPA, 01/07/2010). During this time, allegations that political influences were enabling Aurora's bid for Grootvlei to remain in place were made by Solidarity (Prinsloo, 12/08/2010). Certainly, Enver Motala, the lead liquidator, implied this, saying that 'Aurora's BEE credentials were impressive' (Groenewald \& Rawoot, 26/03/2010). Despite the urgency with which AMD pumping and treatment needed to be undertaken, by mid-2010, the six of the virtually new heavy duty pumps were removed by Aurora, who claimed the pumps had to be relocated to a higher level to protect them from possible flooding of the shaft (Bell 2011). The pumps were never reinstalled. Rather, they were sold off as scrap (Groenwald, 11/06/2010). As reports claimed that Aurora had also sold off other mine infrastructures, for scrap, such as the Cons Modder Ndlovu Shaft No 6, the ore-crushing and the gold-smelting plant, allegations of asset stripping began to emerge (Creamer, $30 / 07 / 2010)$. By this stage, AMD was flowing untreated into the Blesbokspruit (Creamer, 19/03/2010). This was confirmed by water samples taken by DWS officials (Frankson, $12 / 11 / 2014)$. DWS consequently issued a directive to the mine to both pump and treat the AMD. In May 2010, it was announced that criminal charges for ignoring the directive and polluting the Blesbokspruit had been laid against Aurora directors (Groenewald \& Rawoot, 14/05/2010; SABCs 50/50, 07/06/2010; Kardas-Nelson, 26/11/2010). As Grootvlei only had two pumps left, by July 2010 only 40 megalitres of AMD was being pumped per day, causing the mine to flood. This prompted a site visit by Marius Keet of DWS, accompanied by the Democratic Alliance, South Africa's official opposition party. Keet was assured that pumping equipment had been acquired and would be installed within days (Jonck, 27/07/2010). In August 2010 when it was apparent that this had not occurred, Aurora said it needed to repair the pumping equipment, but pumping at full capacity would resume within days and the electricity to do so had been secured from Eskom. Mine management denied that untreated AMD was flowing into the Blesbokspruit. Subsequently, Marius Keet indicated that the matter had been dealt with 'at ministerial level' (in SAPA, 04/08/2010).

Owing to the ongoing non-payment of wages, Solidarity requested an insolvency inquiry relating to the activities of the directors of Aurora and their business consultants. In September 2010, Solidarity indicated that progress had been made into the matter and that a Companies Act Section 424 application, which holds directors personally responsible for the mismanagement of a company, had been made (Keepile, 07/09/2010). In response to a Labour Court ruling, brought by Solidarity and NUM, in December 2010, Aurora ${ }^{7}$ paid over R2 million to the Department of Labour, who, in turn, paid some R800 000 to 240 miners in outstanding wages (Prinsloo, 25/01/2011). Although Aurora owed 1400 workers their wages (totalling R15 million), not all had lodged official claims and for some their information could not be verified (SAPA, 22/12/2010). Despite the ongoing AMD problems, failure to pay suppliers and workers, Motala maintained that Aurora's listing on the JSE was 'on track' and that funding had been secured from a state-owned mainland Chinese company (in Creamer, 19/11/2010). Jen-Chih Huang (Khulubuse Zuma's business partner) was actively involved in promoting this deal (News24, 22/06/2014). Thus, Aurora was given until 28 February 2011 to come up with the finance to pay for Grootvlei, a decision the employees of the mine did not support (SAPA, 17/12/2010; 22/12/2010, Masondo, 18/01/2011).

By early 2011, only a handful of employees remained. Reports indicated that the rate of underground flooding was increasing and the window of time to save the mine from being rendered unworkable (because of the gold becoming inaccessible) was down to months (Masondo, 18/01/2011; Rawoot, 11/02/2011).

7.Enver Motala said the chairman of Aurora had paid the money from his personal accounts (SAPA, 17/12/2010). Khulubuse Zuma testified to this fact as well (Evan, accounts (SAPA, 17/12/2010). Khulubuse Zuma testified to this fact as well (Evan,
$04 / 05 / 2012)$ and Bertelsmann (25/06/2015) noted that a sum of R35million was paid in the chairman's personal capacity. 
Despite this, the lead liquidator was still adamant that 'Things are $100 \%$ on track. It is just a matter of time. By February 28 [2011] the Chinese company that will partner Aurora must issue guarantees and the deal will go through' (in Masondo, 18/01/2011). NUM indicated that they did not think this was likely due to the history of 'unfulfilled promises' (in Masondo, 18/01/2011). Disillusioned with the lack of payment by Aurora of salaries, union dues and benefits to both its members and even non-members (who wished to be part of the class action) ${ }^{8}$ Solidarity announced that it would seek a High Court liquidation order of the company (Prinsloo, 25/01/2011; SAPA, 16/02/2011). It was also reported that Aurora removed the two remaining pumps (valued at R1 million each) ostensibly to 'protect' them from rising mine water (McKay, 06/02/2011). The removal of the last two pumps meant that by February 2011, all pumping ceased and Goliath Gold had to temporarily shut its Nigel One shaft because of water seeping in from Grootvlei (Rawoot, 11/02/2011; SAPA, 09/06/2011). When Linda Page of DWS was made aware of this, she said there was 'no danger of any flooding' and that her department was 'monitoring the water levels' (in Rawoot, 11/02/2011). In April 2011, Zondwa Mandela, representing Aurora, reported to the Parliamentary Portfolio Committee on Mineral Resources that Grootvlei was suffering from cash-flow problems because of the need to pump and treat AMD, the lack of a pumping subsidy from DWS, illegal miners, as well as the actions of NUM and Solidarity (City Press, 14/04/2011). He also claimed that $80 \%$ of the outstanding wages had been paid. During this time, the Chinese deal fell though and so Aurora was unable to come up with the required funding to pay for Grootvlei. Nevertheless, the High Court gave the directors yet another extension (until 16 August 2011) to come up with the money. This prompted the South African Human Rights Commission (SAHRC) to request the Minister of Mineral Resources to intervene to get the workers paid, to prevent the rise of AMD and to come up with a plan to rehabilitate the mine. SAHRC was concerned that the granting of extensions to Aurora to finance the purchase of the mine had caused many of the resultant problems (SAPA, 15/04/2011).

In May 2011, Solidarity lodged a liquidation application against Aurora, for a sum of R3.1 million (Creamer, 20/05/2011). In the same month, the Master of the Pretoria High Court removed Enver Motala and the KPMG liquidator Gavin Gainsford as liquidators, seemingly based on a report compiled by the other liquidators and submitted to a formal Section 381 of the Companies Act enquiry (Creamer, 23/05/2011; Rawoot, 27/05/2011; SAPA, 21/09/2011). Within days of this decision, the remaining liquidators (with Johan Engelbrecht from Icon Insolvency, as the new lead liquidator), assisted by a private security firm, ousted Aurora from Grootvlei (Creamer, 27/05/2011; 10/06/2011). Motale, blaming the trade unions for his removal, did

8.Solidarity claimed that Aurora failed to pay salaries, failed to pay over pension fund contributions, failed to pay UIF and PAYE, as well as deducted union membership fees but did not pay them over to the union (SAPA, 16/02/2011). This resulted in the fees but did not pay them over to the union (SAPA, 16/02/2011). This resulted in the Mineworker's Pension Fund reporting Aurora to the FSB and
Prosecuting Authority (NPA) (Groenewald \& Rawoot, 26/03/2010). make some effort to get himself reinstated, to no avail (Rawoot, 27/05/2011; Rawoot, 03/06/2011; SAPA, $21 / 09 / 2011$ ). He was also subsequently struck off the role as a liquidator when it emerged that he had been convicted of fraud and theft charges (City Press, 31/08/2014).

At this stage, not much was left of the mine, having being stripped of metal, wood, headgear, infrastructure, pumps and the like, by both Aurora and remaining unpaid mine workers (Rawoot, 27/05/2011; Hawker 26/03/2015). COSATU called for government to investigate the liquidators, the asset stripping that took place and the violation of labour laws (SAPA, 02/06/2011). One Aurora director, Thulani Ngubane blamed the mine itself, the workers, the media and the unions for the fate of the mine and the loss of the Chinese buyer (Rawoot, 03/06/2011). Subsequently, it was claimed that DWA was proceeding with the criminal case, with respect to the AMD pollution, with charges having been laid and advice being sought if the directors and the liquidators should be charged as well (Balzer, Parliamentary Portfolio Committee on Water and Environmental Affairs, AMD public hearings 20 June 2011). The new liquidators denied that they could be held criminally liable, maintaining that they had done all that was necessary to ensure that AMD from Grootvlei would not enter the surface water. This included approaching the DWA with a plan to prevent an AMD decant (Creamer, 17/06/2011; 23/06/2011).

In August 2011 Aurora's directors testified under Sections 417 and 418 of the Companies Act, to the Master of the Pretoria High Court with respect to allegations of asset stripping and cessation of operations at Grootvlei (Groenewald \& Rawoot, 05/08/2011; Prinsloo, 11/08/2011; SAPA, 21/09/2011). On 5 October 2011, Aurora Empowerment Systems was liquidated based on a R9 million claim lodged against the company by a creditor, Copper Eagle (Wolmarans, 25/11/2011). In January 2012, another Aurora creditor, Protea Security, obtained a default judgement against Khulubuse Zuma for R10 million, based on him standing surety for their unpaid claim against Aurora (SAPA, 12/01/2012). In March 2012, lead liquidator Johan Engelbrecht issued Section 424 summonses against Aurora directors with respect to personal liability claims for damages relating to Grootvlei owing to how they had 'managed the affairs of Aurora recklessly with the intent to defraud' (Creamer, 05/03/2012; Engelbrecht in Evans, 04/05/2012). This included the failure to pay workers, stripping of assets, lying about securing funding to purchase the mine, being commercially insolvent while operating Grootvlei and the removal of gold from the mine (Evans, 04/05/2012).

Grootvlei was so irreversibly stripped of equipment and vandalised that it could not be revived as a mine. Gold One and Goliath Gold bought the remnants of the gold processing plant, the office block and the mineral rights for a sum of R70 million in 2012 (Esterhuizen, 18/04/2012; Evans \& Sole, 16/05/2014; Bertelsmann, 25/06/2015). Environmental liabilities were limited to a maximum of R10 million (Esterhuizen, 18/04/2012). Marius Keet had noted that it was unlikely that the mine would have been sold if the sale 
included the transfer of all the environmental liabilities (Parliamentary headings into AMD, 20/06/2011). Thus, most of the environmental liabilities fell to the State. To deal with the AMD problem, DWS applied for authorisation for the construction of an AMD treatment plant at Grootvlei's No. 3 shaft (Mukhuthu, 20/06/2014). As the AMD problem was deemed an emergency, environmental authorisation was granted quickly (as EIA requirements can be ignored if the construction is an emergency), in spite of a public outcry (Mukhuthu, 20/06/2014). The plant is yet to come online (Creamer, 02/07/2015).

As the mine was no longer a going concern, the liquidators laid fraud charges against the directors of Aurora (Evans, 04/05/2012; Hawker, 24/08/2014). A smaller claim for R15.5 million was successfully laid by the liquidators against Faizel and Suliman Bhana, Mohamed Limbada and Zeenat Laher for monies paid to them from Aurora accounts, supposedly as repayments for loans (van Rensburg \& van der Merwe, 21/08/2014; Gifford, 26/09/2014). This ruling was appealed, but later upheld (Hawker, 22/03/2015). The liquidators argued that Aurora had to reinstate and restore the mine to the state it was in when Aurora took over in October 2009 (Rawoot, 03/06/2011). Failure to do so meant that Aurora faced a claim of R1.7 billion for damages, loss of gold sales and unpaid salaries (SAPA, 25/08/2014). At the same time, Sections 417, 418 and 424 hearing into Aurora went ahead. This was heard in camera, and the North Gauteng High Court refused to make the report public, despite a Promotion of Access to Information Act (PAIA) application (Harper, 26/01/2014; Hawker, 24/08/2014). At the time it was claimed because the report made damning findings, there was a potential defamation claim and that criminal charges could be laid (Rossouw in Harper, 26/01/2014; Hawker, 24/08/2014). Judge Bertelsmann finally made the transcripts of the insolvency enquiry public in August 2014. Although the report called for criminal charges to be laid, the Special Investigating Unit (SIA) claimed that only President Zuma could authorise the start of the criminal investigations into Aurora and that 'The Presidency has not given any indication of when the proclamation will be issued' (Boy Ndala in Hawker 24/08/2014). The National Prosecuting Authority (NPA) said they could not investigate, only the South Africa Police Service could, and, as such, referred the Master of the Court's report back to the court (Hawker, 24/08/2014).

The case against the Aurora directors was postponed several times. Delays were attributed to the late filing of court papers by Aurora, their lawyers requesting delays to secure funds and a lack of financial records for Aurora (Creamer, 14/10/2011; Hawker, 19/08/2014). The case was finally heard in 2015 and Judge Bertlesmann ordered that the Aurora directors be held jointly and severally liable, in their personal and private capacities, for the damages to the mine. They were also held liable for the non-payment of mine workers and creditors, as well as for gross negligence and mismanagement (such as routing money from Grootvlei to themselves instead of paying salaries and creditors) (Hawker, 22/03/2015). During the course of the case, it became clear that Aurora had bid for the mine without having the financial resources to pay for them (Maromo, $24 / 03 / 2015)$. The respondents were also ordered to pay the costs of the applicants (Bertelsmann, 25/06/2015). Based on this judgement, the police announced that they were investigating charges of fraud, money laundering, racketeering and misrepresentation (Brigadier Hangwani Mulaudzi in Falanga \& Mabotja, 06/07/2015). The parties did lodge a request to appeal the Bertlesmann ruling, but this met with no success (Mabuza, 18/09/2015). The directors of Aurora approached the Supreme Court of Appeals with an appeal application which was rejected (Crowley \& Prinsloo, 15/02/2016; Makhafola, 12/05/2016). The liquidators are now pursuing the directors and managers for the Aurora debt of R1.7 billion. The case has been postponed till March 2017 (Legalbrief, 01/04/2016). In September 2016, the Bhanas were sequestrated by the North Gauteng High Court and Khulubuse Zuma settled with the liquidators and unions for a sum of R23 million (to be paid over 52 months) for unpaid wages (IOL, 07/09/2016).

\section{Summary and analysis}

Grootvlei was historically a financially marginal mine because of frequent flooding, declining gold ore reserves and volatile gold prices. Thus, Grootvlei often required capital injections and was ill placed to deal with the cost of an AMD problem generated by the entire Eastern Basin. As the difficulties and liabilities of Grootvlei became apparent, various owners put the mine up for sale (Sharife, 21/03/2011). Between 1990 and 2014, Grootvlei underwent multiple changes of owners, with control passing from larger, established, better-funded mining companies to smaller, less well-funded junior ones (Stuijt, 10/03/2010; Salgado, 28/02/2011). These smaller Black Economic Empowerment (BEE) companies may not have fully realised Grootvlei's financial and environmental problems and were certainly not in a financial or knowledge position to deal with them. From 2009 onwards, Grootvlei faltered in meeting its AMD obligations, exposing the Blesbokspruit to untreated AMD decant (Marais, 06/08/2014). This was most certainly an indication of mine managers trying to contain costs. Although the State paid an AMD subsidy, it was insufficient; payments were intermittent and attached to stringent verifiable pumping and treatment regimes.

However, there was a significant change in management practices at Grootvlei when Aurora took control of the mine. Aurora actively hindered the ability of workers to keep the mine operational or meet its AMD obligations by removing (and selling) mine equipment, pumps and headgear. Labour practices also changed. Workers were paid late or not at all and strikes ensued. The pumping and treating of AMD became more intermittent and eventually ceased, leaving the mine permanently flooded and rendering it unworkable. The loss of the underground gold reserves can be taken as a loss to South Africa as all mineral resources are national assets (McKay, 06/02/2011). Of concern is that strikingly similar circumstances, including some of the same people, lead to the closure of the Blyvooruitzicht mine on the West Rand (Humby 2014). 
As a consequence of the eventual liquidation of Aurora and the sale of the remaining assets to Gold One, most of the environmental liabilities passed to the State, with serious implications for the taxpayer (Sharife, 21/03/2011; Marais, 06/08/2014). In March 2014, the DWA announced the State would build an AMD treatment plant costing R319 million, a sum that quickly tripled to R956 million by June 2014. More recently, the plant is said to cost R10 billion (Creamer, 02/07/2015). PG Mavundla, an ANC regional branch head in KwaZulu-Natal and former ANC mayor of Umvoti municipality, has won the contract for the project (Mthethwa, 19/10/2014; Mukhuthu, 20/06/2014). Thus, the actual cost to the South African state associated with the AMD problem has escalated alarmingly. From a state pumping subsidy of between R2.5 and R6 million per month to that of R10 billion capex for a brand new AMD reverse osmosis or ion exchange treatment plant, as well as an estimated ongoing cost of R25 million per month for running costs (Molatlhwa, 19/05/2016).

Despite South Africa's mining and mine rehabilitation legislation placing legal obligations on the directors, this did not prevent (or even mitigate) the situation at Grootvlei. Law enforcement was intermittent, weak and seemingly not viewed as urgent by DWS or DMR, despite the high-level Inter-Ministerial Committee's report indicating that Grootvlei's pumping shaft had to be secured and AMD pumping and treatment had to resume (van der Merwe, 24/02/2011). Although key environmental compliance and enforcement tools such as permits, compliance notices and directives were at the disposal of government officials, very few were used. It has been argued that the AMD crisis at Grootvlei could have been avoided if law enforcement was stronger (Liefferink \& van Eeden 2010). Despite the specialised cabinet commissioned AMD task team urging extreme urgency and action regarding AMD, it is clear such urgency is not government policy (McCarthy 2011).

To date, the DMR has not taken any action against the directors or mine management (McKay, 06/02/2011). Thus, NUM has argued that Aurora 'directors ... are receiving preferential treatment because of their political clout' (Sharife, 21/03/2011). Solidarity also claims the first set of liquidators are partly responsible for the forced mine closure as they did not do due diligence on the directors, nor did they ensure that the mine was run properly while under Aurora's care, despite their legal obligation to preserve the asset (McKay, 06/02/2011; SAPA, 20/05/2011; Marais, 06/08/2014; Hawker, 22/03/2015). In addition, Solidarity and NUM note the Insolvency Act does not offer adequate protection for workers. They argue for tighter regulations over who can be appointed as company directors (30/05/2012,SAPA). There is also need to review South Africa's liquidation laws, as selling a mine in liquidation simply to the highest bidder may not be the best option. Importantly, the new owners should have the relevant experience and skills to run a mine and manage the attendant environmental impacts (Creamer, 27/05/2011; 03/06/2011; Marais, 06/08/2014). In addition, although the DMR has to agree to the mining rights to be transferred in the case of liquidation, the DMR has little legal standing to intervene in liquidations. There is also a compliance gap between mining law which requires mines to obtain a closure certificate and company law which allows a company to be deregistered relatively easily (Marais, 06/08/2014). Furthermore, during the period of liquidation, it is not clear who is responsible for environmental damages (Marais, 06/08/2014). It may be that the sale of near-closure mines to inexperienced, underfunded junior miners undermines the duty of care obligations embedded in mine closure legislation. The events pertaining to ownership, operations and management of Grootvlei is crucial for highlighting responsibilities pertaining to AMD. South Africa's environmental legislation framework (which encompasses AMD) is strong, but it is clear that a combination of political will and amended legislation is needed to effectively tackle abandoned mines and attendant environmental liabilities (Humby 2014). Because the 'environment as a creditor' is not prioritised and has no 'special call' on a company's assets, it behoves the State as custodian of the environment to shoulder its responsibility and uphold its creditor rights with respect to the liability of mine closure rehabilitation.

\section{Conclusion}

Grootvlei was a marginal mine, hobbled by inheriting responsibility for pumping and treating AMD for the entire Eastern Basin. Its financial difficulties resulted in its continual change in ownership, as mine companies sought to offload an underperforming, near end-of-life asset. Until 2009, however, Grootvlei was operational, paying wages and fulfilling its AMD obligations (albeit intermittently and with difficulty). The situation changed radically when Aurora took control. Mining activities ceased; mine infrastructure was dismantled and sold for scrap; AMD was no longer pumped or treated, and mineworkers went unpaid. The mine is now permanently closed. AMD now continues to rise and will certainly decant in time (DWA 2011). Despite comprehensive environmental legislation, the mine owners, mine managers and the various government officials (who should have prevented such flagrant violations) have not been brought to book. In addition, the destruction of this mine has created the impression that laws can be flouted with impunity. Fortunately, the determination of the second set of liquidators to pursue the Aurora directors civilly resulted in a judgement holding them liable for the nonpayment of workers and the destruction of the Grootvlei and Cons Modder infrastructure.

\section{Acknowledgements}

The authors are deeply grateful to Wendy Job of the UJ Cartographic unit for the maps. The authors also thank Andrew Karam for sourcing the media articles and some of the literature.

\section{Competing interests}

The authors declare that they have no financial or personal relationships which may have inappropriately influenced them in writing this article. 


\section{Authors' contributions}

T.J.M.M was the Project Leader; she analysed the data and wrote and edited the manuscript. M.M. wrote and edited the manuscript.

\section{References}

Baartjes, N.L. \& Gounden, K.G., 2012, Causes of mine decline in South Africa, EcoPartners, Johannesburg.

Barradas, F.V. \& Loggenberg, A.P., 1996, Investigation of surface water ingress to the East Rand Basin, Directorate Mine Surveying - Minerals and Energy Affairs, Pretoria.

Bell, T., 2011, Aurora's golden greed and liability hopes, WordPress, viewed 8 February 2016, from http://terrybellwrites.com/2011/12/02/auroras-golden-greed-andliability-hopes/

Blowes, D.W., Ptacek, C.J., Jambor, J.L. \& Weisener, C.G., 2014, 'The geochemistry of acid mine drainage', Treatise on Geochemistry 9, 149-204. http://dx.doi. org/10.1016/b978-0-08-095975-7.00905-0

Bremmer, L., 2013, 'The political life of rising acid mine water', Urban Forum 24, 463-483.

Department of Environmental Affairs and Tourism (DEAT), 1998, 'National Environmental Management Act No. 107 of 1998 (NEMA)', Government Gazette vol. 401, no. 19519.

Department of Water Affairs and Forestry (DWAF), 1998, National Water Act No. 36 of 1998 (NWA), Government Gazette vol. 71, no. 31417.

Department of Water Affairs (DWA), 2011, 'Mine water management in the Witwatersrand Goldfields with special emphasis on acid mine drainage', Meetin no 4, Strategy Steering Committee of the Vaal River System. Department of Wate Affairs, Johannesburg, 13 April.

de Wet, L. \& Sidu, S., 2013, 'Water quality and compliance monitoring of treated underground and surface water at the Grootvlei Proprietary Mines and the Blesbokspruit wetland, Springs, South Africa', Proceedings of the International Mine Water Association, Golden, Colorado, viewed 7 June 2016, from http:// mwen.info/docs/imwa_2013/IMWA2013_deWet_501.pdf

Dini, J., 1998, Blesbokspruit Ramsar Information Sheet, viewed 9 March 2016, from https://rsis.ramsar.org/RISapp/files/RISrep/ZA343RIS.pdf

Durand, J.F., 2012, 'The impact of gold mining on the Witwatersrand on the rivers and karst system of Gauteng and North West Province, South Africa', Journal of African Earth Sciences 68, 24-43. http://dx.doi.org/10.1016/j.jafrearsci.2012.03.013

Eisenhardt, K.M. \& Graebner, M.E., 2007, 'Theory building from cases: Opportunities and challenges', The Academy of Management Journal 50(1), 25-32. http://dx. doi.org/10.5465/AMJ.2007.24160888

Ewart, T.I., 2011, 'Acid mine drainage in the Gauteng Province of South Africa - A phenomenological study on the degree of alignment between stakeholders concerning a sustainable solution to acid mine drainage', Masters dissertation, University of Stellenbosch, Stellenbosch.

Fourie, M., 2009, Acid mine drainage for Witwatersrand Gold Mines. Environmental law remedies available to regulators and civil society, Johannesburg, viewed 17 February 2016, from http://cer.org.za/wp-content/uploads/2011/01/MelissaFourie-on-AMD-Oct-2009.pdf

Hobbs, P., Oelofse, S.H. \& Rascher, J., 2008, 'Management of environmental impacts from coal mining in the Upper Olifants River catchment as a function of age and scale', Water Resources Development 24(3), 417-431. http://dx.doi.org/10.1080/ 07900620802127366

Hobbs, P.J. \& Cobbing, J.E., 2007, A hydrogeological assessment of acid mine drainage impacts in the West Rand Basin, Gauteng Province, CSIR, Pretoria, viewed 27 October 2016, from http://researchspace.csir.co.za/dspace/handle/10204/3348

Humby, T., 2014, 'Facilitating dereliction? How the South African legal regulatory framework enables mining companies to circumvent closure duties', in I.M. Weiersbye, A.B. Fourie, M. Tibbett \& K. Mercer (eds.), Mine closure 2014, University of the Witwatersrand, Johannesburg: 1-17.
Jones \& Wagener (Pty) Ltd., 2003, Grootvlei Proprietary Mines (Pty) Ltd., A subsidiary of Petrex (Pty) Ltd.: Feasibility study on the reduction of surface water inflows to of Petrex (Pty) Ltd.: Feasibility study on the reduction of surface water inflows to
the underground workings, Report No. JW101/03/8894, Jones \& Wagener (Pty) the underground
Ltd., Sandton.

Lea, I., Waygood, C. \& Duthie, A., 2003, 'Water management strategies to reduce long-term liabilities at Grootvlei Gold Mine', in Proceedings of the 8th International Congress on Mine Water and the Environment, Johannesburg viewed 8 February 2016, from http://www.imwa.info/docs/imwa_2003/imwa 2003_441-449.pdf

Liefferink, M. \& van Eeden, E.S., 2010, 'Proactive environmental activism to promote the remediation of mined land and acid mine drainage: A success story from the South African goldfields', in Proceedings of the International story fouter Association, Sydnold Mine Water Association, Sydney, Nova Scotia, pp. 537-540, viewed 7 June
2016, from https://www.imwa.info/docs/imwa_2010/IMWA2010_Liefferink_

McCarthy, T.S., 2010, Decanting of acid mine water in the Gauteng city-region: Analysis, prognosis and solutions, GCRO, Johannesburg.

McCarthy, T.S., 2011, 'The impact of acid mine drainage in South Africa', South African Journal of Science 107, 1-7. http://dx.doi.org/10.4102/sajs.v107i5/6.712

Milaras, M., Ahmed, F. \& McKay, T.J.M., 2014, 'Mine closure in South Africa: A survey of current professional thinking and practice', in I.M. Weiersbye, A.B. Fourie, M. Tibbett \& K. Mercer (eds.), Mine closure 2014, University of the Witwatersrand, Johannesburg.

Murphy, N., Taylor, J. \& Leake, M., 2012, Coming to terms with acid mine drainage, viewed 8 February 2016, from http://www.earthsystems.com.au/wp-content/ uploads/2012/03/BestPrac_Acid_Drainage.pdf

Palmer, M., Waygood, C. \& Lea, I., 2006, 'Case study on the remediation of water ingress to old gold workings linked to active mining areas in South Africa', in Proceedings of the 7th International Conference on Acid Rock Drainage (ICARD) St. Louis, viewed 8 February 2016, from http://www.asmr.us/Publications/ Conference \%20Proceedings/2006/2281-Waygood-ZA.pdf

Paterson, A. \& Kotzé, L.J., 2009, Environmental compliance and enforcement in South Africa: Legal perspectives, Juta Law, Cape Town.

Plaut, M., 2011, Mandela and Zuma gold mine 'exploiting workers', BBC Radio 4, Crossing Continents, viewed 8 February 2016, from http://www.bbc.com/news/ world-africa-13275704

Plaut, M., 2013, Johannesburg: Who pays for a century of mining? WordPress, viewed 8 February 2016, from http://martinplaut.wordpress.com/2013/05/23/ johannesburg-who-pays-for-a-century-of-mining

Scott, R., 1995, Flooding of Central and East Rand gold mines. An investigation into controls over the inflow rate, water quality and predicted impacts of flooded mines, Report No. 486/1/95, WRC Pretoria.

Strydom, H.A. \& King, N.D., 2009, Environmental management in South Africa, 2nd edn., Juta Law, Cape Town.

Thorius, T., 2004, 'The effect of Grootvlei mine water on the Blesbokspruit', Masters dissertation, University of Johannesburg, Johannesburg.

Tutu, H., McCarthy, T.S. \& Cukrowska, E., 2008, The chemical characteristics of acid mine drainage with particular reference to sources, distribution and remediation: The Witwatersrand Basin, South Africa a case study, Applied remediation: The Witwatersrand Basin, South Africa a case study, Applied 09.002

Van der Merwe, W. \& Lea, I., 2003: 'Towards sustainable mine water treatment at Grootvlei Mine', in Proceedings of the 8th International Congress on Mine Water and the Environment, Johannesburg South Africa, viewed 8 February 2016, from http://www.imwa.info/docs/imwa_2003/imwa_2003_025-036.pdf

Wates, Meiring \& Barnard (Pty) Ltd., 2002, Integrated water management plan, Geohydrological investigation, Sappi Enstra, Springs.

Winde, F. \& Stoch, E.J., 2010, 'Threats and opportunities for post-closure development in dolomitic gold mining areas of the West Rand and Far West Rand (South Africa) - A hydraulic view part 1: Mining legacy and future threats', Water SA 36(1), 69-74. http://dx.doi.org/10.4314/wsa.v36i1.50908

Yin, R.K., 2011, Applications of case study research, Sage, Los Angeles, CA. 